\title{
Empirical Analysis of Technology Innovation to Promote the International Competitiveness of China's Manufacturing Industry
}

\author{
Long Wei, Qi Luo \\ School of Economics, Wuhan University of Technology, Wuhan, China \\ Email: 18390248667@163.com
}

How to cite this paper: Wei, L., \& Luo, Q. (2022). Empirical Analysis of Technology Innovation to Promote the International Competitiveness of China's Manufacturing Industry. American Journal of Industrial and Business Management, 12, 21-34. https://doi.org/10.4236/ajibm.2022.121003

Received: December 24, 2021

Accepted: January 23, 2022

Published: January 26, 2022

Copyright $\odot 2022$ by author(s) and Scientific Research Publishing Inc. This work is licensed under the Creative Commons Attribution International License (CC BY 4.0).

http://creativecommons.org/licenses/by/4.0/ (c) (i) Open Access

\begin{abstract}
The "Made in China 2025" focuses on the new environment and new issues facing the long-term development of China's manufacturing industry, and aims to fundamentally improve China's international competitiveness of the manufacturing industry. The competitive advantage of the manufacturing industry will change dynamically under the impetus of continuous technological innovation, but it is not easy to conclude whether the impact is facilitating or inhibiting. This paper presents an empirical analysis of the relationship between technological innovation and international competitiveness in ten manufacturing industries using panel data for the period 2012-2016 selected based on certain criteria. It was found that innovation investment may enter the stage of diminishing marginal benefits, the introduction and absorption of re-innovation capacity can significantly improve the international competitiveness of the manufacturing industry, innovation output capacity is not significant, and the role of a technological innovation support system that only considers financial security is also not significant. Policy recommendations are made accordingly.
\end{abstract}

\section{Keywords}

Manufacturing, International Competitiveness, Technology Innovation

\section{Introduction}

With China's economic development stage gradually into the late industrialization, China's economy began to enter the "new normal" phase of medium-to-highspeed development from the high-speed growth stage. Manufacturing is the leading force of China's industrialization and modernization, and it is also an im- 
portant foundation for China's economic growth and transformation. However, the phenomenon that China's manufacturing technology is locked in the mature stage is relatively prominent, and the high-end production equipment and core components technology in traditional industries have been restricted for a long time, with a large gap in technological competitiveness; China's competitiveness in key global emerging technologies is still insufficient (Huang \& He, 2015). How to enhance the motivation of the whole society for continuous investment in basic research is the decisive factor to decide whether China's manufacturing industry can leap from mature technology advantage to frontier technology advantage and emerging technology advantage in the future.

To clarify the mission objectives, specific tasks, required conditions, and promotion measures for the development of China's manufacturing industry, the government needs to formulate a "strategic plan for industrial-strength" that meets the global, systematic, long-term, and internationally competitive requirements (Huang, 2012). The "Made in China 2025" is such a landmark document in the history of China's industrial development. It focuses on the new environment and new problems facing the long-term development of China's manufacturing industry, and aims to fundamentally improve the international competitiveness of China's manufacturing industry under the new technological environment, international competitive environment and domestic factor environment in the future.

The essence of economic development and technological progress is a process of continuously acquiring technological capabilities and transforming these capabilities into product and process innovations in the process of constant technological change, i.e., the development of the industry is a process of capability construction (Kim \& Nelson, 2000). The resources or capabilities that can bring sustainable competitive advantage cannot be traded, therefore, enterprises can only gradually build their core capabilities and resources in the process of development exploration. Moreover, such endogenous and cumulative development can only be achieved through consistent investment.

Therefore, this paper starts from the realistic background of enhancing the international competitiveness of China's manufacturing industry, and conducts relevant research on the theme of the impact of technological innovation on the competitiveness of the international manufacturing industry. The paper is organized as follows.

Firstly, this paper elaborates on the necessity of enhancing the international competitiveness of China's manufacturing industry in the light of China's actual situation, and explores the relationship between the two in depth from the perspective of technological innovation.

Second, this paper divides technological innovation into the technological innovation capability system and the technological innovation support system, and composes the literature on technological innovation and the international competitiveness of the manufacturing industry, so as to present the marginal contribution of this paper's research. 
Third, this paper examines the screening and selection of samples before the empirical evidence, according to the availability of data and the classification of national economy industries, then at the same time combined with the study of the explanatory variables of international competitiveness in this paper, the basis of sample selection is explained, and this paper selects the industries that have both carried out a considerable degree of technological innovation activities and have a certain market overseas and a certain degree of openness as the samples for the study.

Fourthly, after the explanation of index setting and sample selection, this paper establishes the influence model between technological innovation and international competitiveness of the manufacturing industry, adds control variables to analyze the relationship between them empirically, and provides a reasonable explanation of the empirical results.

Fifth, this paper puts forward corresponding policy suggestions in response to the empirical results, and tries to provide some reference opinions for the improvement of the international competitiveness of China's manufacturing industry.

\section{Literature Review}

The development of China's foreign trade depends on the international competitiveness of its export products. In terms of the composition of export products, trade in industrial manufactures is the mainstream of international trade. Therefore, enhancing the international competitiveness of industrial manufactured products is an important issue facing the development of China's foreign trade (Lai, Wang, \& Wu, 1999). The so-called international competitiveness is the productivity of a particular industry of a country reflected by the sale of its products in the international market. In a market economy, the key aspects of economic activities are production efficiency and marketing, and the international competitiveness of an industry is ultimately measured and tested by the market share of its products; the pursuit of economic efficiency in industrial societies and the production of as much output as possible with as little input as possible is the "central principle" of human activities. Therefore, international competitiveness is ultimately the productivity of the same industry or similar enterprises in each country compared with each other.

The market competitiveness of an industry or product depends on two direct factors: cost and product differentiation (Jin, 1996). With the impetus of continuous technological innovation, the competitive advantage of the manufacturing industry will change dynamically, i.e., the initially non-advantaged industry increases its relative productivity, which lowers the production cost per unit of product, which in turn lowers the product price, leading to an increase in domestic and foreign market demand. The expansion of the market scale and the increase of profits will further stimulate enterprises to expand the production scale and attract the entry of enterprises outside the industry. The internal scale economy and the external scale economy of the industry further reduce the production cost of goods, thus 
improving the international competitiveness of the industry through the cost competitive advantage. Second, technological innovation through product production diversification, product quality improvement, the formation of a competitive advantage of differentiation. In the mature stage of industry development, effective technological innovation can develop new products, increase product variety, and improve product performance and quality, thus meeting the diversified needs of consumers. As a non-price barrier, product differentiation enables consumers to form preferences for certain brands of products and reduces substitutability among products, thus changing the market structure to non-perfect competition or oligopolistic, so as to gain monopoly profits by virtue of market power, thus enhancing the international competitiveness of manufacturing industries.

Brecht analyzed the relationship between industrial competitiveness and R \& $\mathrm{D}$ costs, and showed that $\mathrm{R} \& \mathrm{D}$-intensive industrial sectors promote both exports and imports and exhibit a strong competitive advantage (Brecht, 1992). Greenhalg et al. analyzed the role of technological innovation activities in the UK manufacturing industry on its competitiveness and showed that technological innovation has a significant driving effect on mature industries, while it has a significant effect on high-tech industries in the short and medium term (Greenhalgh et al., 1996). Demirel \& Mazzucato studied the pharmaceutical industry in the United States and found that technological innovation only affects the growth rate of firms with specific characteristics, such as making continuous innovation investments, having biotechnology alliances, and being small. Technology alliances, and are small in size (Demirel \& Mazzucato, 2008). Domestic empirical studies have also shown different or even contradictory findings. Junhong Bai used the data of Chinese large and medium-sized industrial enterprises by industry from 1998 to 2007 as a sample and found that government R \& D funding is an important facilitator of technological innovation in Chinese industrial enterprises (Bai, 2011), while Miao Miao Li et al. used 216 listed enterprises in China's strategic emerging industries as a sample and found that the relationship between fiscal policy and technological innovation capacity of enterprises in strategic emerging industries is non-linear (Li et al., 2014). Li Lianshui et al. used a modified Cobb-Douglas form of the knowledge production function to find that the investment in innovation funds in China has a driving effect on the improvement of manufacturing innovation capability, but the investment in innovation personnel has a suppressive effect on innovation capability; Wu Xianjin et al. found that the number of R \& D personnel has a significant positive effect on the independent innovation capability in the Pan-PRD region, but the effect of $\mathrm{R} \&$ $\mathrm{D}$ The effect of $\mathrm{R} \& \mathrm{D}$ personnel on innovation capability in the Pan-PRD region was found to be positive, but the effect of R \& D investment was not significant (Wu \& Shi, 2010). Using the Chinese manufacturing industry as a sample, Qinchang Li et al. empirically concluded that technological innovation can enhance the value added of exports, thus improving global competitiveness ( $\mathrm{Li}$ 
et al., 2019). From these empirical evidences above, it can be seen that the impact of technological innovation on manufacturing cannot be generalized, but the relevant contextual factors should be carefully examined to address the relevant issues and analyze the intrinsic mechanisms by means of empirical studies.

To sum up, the relationship between technological innovation and international competitiveness of manufacturing industry is not clear, and the research mainly focuses on the influence of technological innovation on a certain economic factor or the one-way effect of certain variables on international competitiveness of manufacturing industry, and the relationship between the two is rarely studied from a comprehensive and multi-angle perspective from the specific actual situation of China. Therefore, this paper takes the influence of technological innovation on international competitiveness of manufacturing industry as the theme, explores the influence mechanism of technological innovation on international competitiveness of manufacturing industry in depth, and breaks the previous research paradigm of single measure of technological innovation index, and measures technological innovation from two dimensions of technological innovation capacity system and technological innovation support system, so as to reveal the influence of technological innovation on international competitiveness of manufacturing industry in a more comprehensive way. The impact of technological innovation on the international competitiveness of manufacturing industry can be revealed more comprehensively. At the same time, the impact of technological innovation is specifically studied in Chinese manufacturing industry, which can provide reference significance for the healthy and stable development of Chinese manufacturing industry.

\section{Sample Selection, Indicator Setting and Data Source}

\subsection{Sample Selection}

This paper focuses on the correlation between technological innovation in manufacturing industry and the international competitiveness of its products. According to the National Economic Classification of Industries (GB/T 4754-2011), China's manufacturing industry includes a total of 31 sub-sectors with two-digit codes from 13 - 43. In order not to lose focus, it is necessary to analyze those industries that both carry out a considerable degree of technological innovation activities and have a certain degree of openness in overseas markets. The R \& D investment intensity is used to initially characterize the degree of technological innovation in manufacturing, calculated by the formula: amount of industry R \& D expenditure/industry sales revenue. The ratio of industry exports to industry sales revenue is used to initially characterize the degree of openness of the industry. The above two ratios are multiplied together and the top ten industries are taken as the sample of this paper. The measurement results obtained based on the relevant data of each industry in 2016 are shown in Table 1. The top ten industries are: computer, communication and other electronic equipment manufacturing, 
Table 1. Sample selection basis. Author's calculations.

\begin{tabular}{|c|c|c|c|c|}
\hline Number & Industry & $\begin{array}{l}\mathrm{R} \& \mathrm{D} \text { investment } \\
\text { intensity }\end{array}$ & Openness & $\begin{array}{l}\text { Multiplication } \\
\text { term }\end{array}$ \\
\hline 1 & $\begin{array}{l}39 \text { computer, communications and other electronic equipment } \\
\text { manufacturing }\end{array}$ & 1.7217 & 47.8191 & 0.8233 \\
\hline 2 & 43 metal products, machinery and equipment repair industry & 1.2528 & 36.1035 & 0.4523 \\
\hline 3 & $\begin{array}{l}37 \text { railway, shipbuilding, aerospace and other transportation } \\
\text { equipment manufacturing }\end{array}$ & 1.8941 & 16.7940 & 0.3181 \\
\hline 4 & 40 instrumentation Manufacturing & 1.8309 & 14.3856 & 0.2634 \\
\hline 5 & 38 electrical machinery and equipment manufacturing & 1.3672 & 13.6080 & 0.1860 \\
\hline 6 & 41 other manufacturing & 0.8961 & 16.4159 & 0.1471 \\
\hline 7 & 34 general equipment manufacturing & 1.2884 & 10.2012 & 0.1314 \\
\hline 8 & $\begin{array}{l}24 \text { cultural, educational, industrial and beauty, sports and } \\
\text { entertainment products manufacturing }\end{array}$ & 0.5033 & 26.0262 & 0.1310 \\
\hline 9 & 35 special equipment manufacturing industry & 1.4255 & 8.0280 & 0.1144 \\
\hline 10 & 21 furniture manufacturing & 0.4427 & 20.2376 & 0.0896 \\
\hline 11 & 29 rubber and plastic products industry & 0.7783 & 11.4248 & 0.0889 \\
\hline 12 & 18 textile and apparel, apparel industry & 0.4154 & 20.0646 & 0.0833 \\
\hline 13 & 27 pharmaceutical manufacturing & 1.5698 & 5.1391 & 0.0807 \\
\hline 14 & 19 leather, fur, feathers and their products and footwear industry & 0.3562 & 22.2685 & 0.0793 \\
\hline 15 & 33 metal products industry & 0.7731 & 9.2295 & 0.0714 \\
\hline 16 & 28 chemical fiber manufacturing & 0.9839 & 7.1062 & 0.0699 \\
\hline 17 & 36 automotive Manufacturing & 1.2066 & 3.9644 & 0.0478 \\
\hline 18 & 26 chemical raw materials and chemical products manufacturing & 0.9094 & 4.9933 & 0.0454 \\
\hline 19 & 17 textile industry & 0.5006 & 8.7415 & 0.0438 \\
\hline 20 & 31 ferrous metal smelting and rolling processing industry & 0.8119 & 3.8448 & 0.0312 \\
\hline 21 & 23 printing and recording media reproduction industry & 0.5263 & 5.8851 & 0.0310 \\
\hline 22 & 22 paper and paper products industry & 0.7715 & 3.8416 & 0.0296 \\
\hline 23 & 14 food manufacturing & 0.5906 & 4.7334 & 0.0280 \\
\hline 24 & $\begin{array}{l}20 \text { wood processing and wood, bamboo, rattan, palm and } \\
\text { grass products industry }\end{array}$ & 0.3198 & 5.9011 & 0.0189 \\
\hline 25 & 32 non-ferrous metal smelting and rolling processing industry & 0.7730 & 2.2997 & 0.0178 \\
\hline 26 & 13 agricultural and sideline food processing industry & 0.3271 & 4.1191 & 0.0135 \\
\hline 27 & 30 non-metallic mineral products industry & 0.4712 & 2.8166 & 0.0133 \\
\hline 28 & 15 liquor, beverage and refined tea manufacturing & 0.4631 & 1.3460 & 0.0062 \\
\hline 29 & 25 petroleum, coal and other fuel processing industries & 0.3264 & 1.7907 & 0.0058 \\
\hline 30 & 16 tobacco products industry & 0.1830 & 0.4657 & 0.0009 \\
\hline
\end{tabular}

Note: The data source is China Science and Technology Statistical Yearbook (2017), China Industrial Statistical Yearbook (2017); 42 represents industry codes with missing data. 
metal products, machinery and equipment repair, railroad, ship, aerospace and other transportation equipment manufacturing, instrumentation manufacturing, electrical machinery and equipment manufacturing, other manufacturing, general equipment manufacturing, cultural, educational, industrial, aesthetic, sports and entertainment goods manufacturing, special equipment manufacturing, and furniture manufacturing. However, since the metal products, machinery and equipment repair and other manufacturing industries are not easy to correspond with the SITC (Rev. 3) trigonometric classification codes, which makes subsequent analysis difficult, these two industries are replaced by the rubber and plastic products and textile, clothing and apparel industries, which rank eleventh and twelfth. Table 1 shows a description of the sample selection related to this paper.

Table 1 shows the basis of sample selection.

\subsection{Indicator Setting}

In this paper, the Revealed Comparative Advantage (RCA) index is used as the explanatory variable to measure the international competitiveness of Chinese manufacturing products.

$$
\operatorname{RCA}_{i j}=\frac{x_{i j} / x_{i}}{x_{w j} / x_{w}}
$$

$\mathrm{RCA}_{i j}$ denotes the displayed comparative advantage index of product $j$ in country $i, X_{i j}$ denotes the export value of product $j$ in country $i, X_{i}$ denotes the export value of all products in country $i, X_{w j}$ denotes the total export value of product $j$ worldwide, and $X_{W}$ denotes the total export value of all products in all countries in the world. Generally, if $\mathrm{RCA}_{i j}<1$, the international competitiveness of country $i$ s product $j$ is weak on the surface; if $\mathrm{RCA}_{i j}>1$, the international competitiveness of product $j$ of country $i$ is stronger. A larger index of indicative comparative advantage indicates the more competitive the class of products is in the international market.

Referring to $\mathrm{Yu}$ Mingyuan, this paper divides the core explanatory variables into technological innovation capability system variables and technological innovation support system variables ( $\mathrm{Yu}, 2014)$. Technological innovation capability system includes: innovation input capability, innovation output capability, and introduction and absorption and re-innovation capability. The technological innovation support system, on the other hand, includes both government support and financial institution support.

First of all, let's look at the technological innovation capability system. Innovation input capability refers to the industry's ability to invest in the corresponding elements in R \& D activities, and the strength of investment in innovation funds is taken as its quantitative index, calculated as follows: industry R \& D expenditure amount/industry sales revenue of the year; innovation output capability refers to the industry's ability to achieve cost reduction, market creation or revenue expansion through technological innovation, and the ratio of new product sales revenue is chosen as its quantitative index, calculated as follows Industry sales 
revenue of new products/industry sales revenue of the year; the introduction and absorption capacity refers to the industry's ability to complete its own technological progress through technology introduction and learning and absorption, and the ratio of absorption and digestion expenses is chosen as its quantitative index, calculated as follows: industry digestion and absorption expenses/industry technology introduction expenses.

For the support system of technological innovation, this paper focuses on the aspect of financial support. The biggest problem that manufacturing enterprises will encounter in the process of technological innovation is the lack of funds, and the lack of sufficient resources will seriously disturb the smooth and steady development of technological innovation activities. The sources of funds are mainly government and financial institutions, and the corresponding quantitative indexes are set as follows: the ratio of government funds obtained by the industry to the total amount of funds for scientific and technological activities in the industry represents the government support; the ratio of financial funds obtained by the industry to the total amount of funds for scientific and technological activities in the industry is used as the financial support (Hu \& Liu, 2015).

The control variables are the proportion of the industry's product sales revenue to the overall sales revenue of the manufacturing industry as the quantitative index of the industry's scale, and the proportion of the industry's import and export trade volume as the quantitative index of its market openness, respectively, to exclude the influence of the manufacturing industry's production scale and openness to the outside world on the international competitiveness of its products. The formula of market openness is as follows: (total import of the industry in the year + total export of the industry in the year)/total industrial output value of the industry.

\subsection{Data Sources}

The raw data required for the RCA index values and the import data of manufacturing industries are obtained from the UN Comtrade database, which are organized and calculated according to the correspondence between the three-digit product classification of SITC (Rev. 3) and the two-digit manufacturing industries of the National Economic Classification of Industries. The other raw data in the variables of technological innovation capability system, technological innovation support system and control variables were obtained from the China Science and Technology Statistical Yearbook and the China Industrial Statistical Yearbook from 2013-2017.

\section{Empirical Analysis}

\subsection{Model Design}

In this paper, the RCA index reflecting international competitiveness is used as the explanatory variable, and the quantitative indicators such as manufacturing technology innovation capability system and technology innovation support sys- 
tem are used as the main explanatory variables, and relevant control variables are selected to eliminate the interference from other aspects and highlight the role played by technology innovation system. Meanwhile, in order to eliminate heteroskedasticity and take elasticity analysis, logarithms are taken for all variables. The basic form of the model is as follows:

$$
\begin{aligned}
\operatorname{lnRCA}{ }_{i t}= & \beta_{0}+\beta_{1} \ln \mathrm{IIN}_{i t}+\beta_{2} \ln \mathrm{IOUT}_{i t}+\beta_{3} \ln \mathrm{INAB}_{i t}+\beta_{4} \ln \mathrm{GOV}_{i t} \\
& +\beta_{5} \ln \mathrm{FIN}_{i t}+\beta_{6} \ln \mathrm{SCA}_{i t}+\beta_{7} \ln \mathrm{OPE}_{i t}+\varepsilon_{i t}
\end{aligned}
$$

where: $\beta_{0}$ is the constant term, $\beta_{1}-\beta_{7}$ are the parameters to be estimated, and the subscripts $i$ and $t$ denote the sample industries and time, respectively RCA is the displayed comparative advantage index, IIN is the innovation funding intensity, OUT is the new product sales revenue ratio, INA is the absorption and digestion funding ratio, IGOV is the government support, FIN for financial support efforts, SCA is the industry size, and OPE is the market openness. The descriptive statistics of all variables are shown in Table 2.

Table 2 shows the descriptive statistics of this paper.

\subsection{Empirical Results and Analysis}

Table 3 shows the regression results for testing the model.

Regressions were calculated using Stata15 to obtain the correlation regression coefficients as shown in Table 3. Firstly, it is assumed that there is no individual effect and mixed regression is used to estimate the parameters. It can be seen that the technology innovation capability system variables pass the significance test, while the technology innovation support system variables are insignificant, and the market size of the control variables pass the significance test while the market openness is insignificant. The fixed-effects regression model can be used to determine whether to use mixed regression or fixed-effects model. The results show that fixed effects are significantly better than mixed regressions, and each individual should be allowed to have its own intercept term. The results are shown in the third column. The above results basically confirm the existence of individual

Table 2. Descriptive statistics of variables. Author's calculations.

\begin{tabular}{cccccc}
\hline Variables & Samples & Mean & Variance & Min. & Max. \\
\hline RCA & 50 & 0.679 & 0.661 & 0.076 & 2.538 \\
IIN & 50 & 0.011 & 0.006 & 0.002 & 0.019 \\
IOUT & 50 & 0.174 & 0.09 & 0.051 & 0.354 \\
INAB & 49 & 0.447 & 0.383 & 0.048 & 2.198 \\
GOV & 50 & 0.051 & 0.062 & 0.006 & 0.259 \\
FIN & 50 & 0.932 & 0.066 & 0.716 & 0.983 \\
SCA & 50 & 0.035 & 0.026 & 0.007 & 0.095 \\
OPE & 50 & 0.621 & 0.484 & 0.195 & 2.282 \\
\hline
\end{tabular}


Table 3. Regression results. Author's calculations.

\begin{tabular}{|c|c|c|c|}
\hline Variables & $\mathrm{RE}$ & $\mathrm{FE}$ & OLS \\
\hline $\operatorname{lnIIN}$ & $-0.4863^{\star *}(-2.57)$ & $-0.3335(-1.65)$ & $-2.5542^{\star * \star}(-6.50)$ \\
\hline $\operatorname{lnIOUT}$ & $0.0310(0.15)$ & $-0.0384(-0.19)$ & $2.5868^{\star * \star}(4.39)$ \\
\hline $\ln I N A B$ & $0.0511^{\star \star}(2.06)$ & $0.0419(1.62)$ & $-0.2614^{\star \star}(-2.33)$ \\
\hline $\operatorname{lnGOV}$ & $-0.0070(-0.13)$ & $0.0206(0.39)$ & $-0.3525(-1.37)$ \\
\hline $\ln F I N$ & $0.5192(0.55)$ & $0.4734(0.49)$ & $0.5274(0.21)$ \\
\hline $\operatorname{lnSCA}$ & $0.8316^{\star \star \star}(3.43)$ & $1.0228^{\star \star}(2.68)$ & $0.3954^{\star \star}(2.40)$ \\
\hline $\ln \mathrm{OPE}$ & $0.1002(0.85)$ & $0.2472^{\star}(1.80)$ & $-0.1904(-1.25)$ \\
\hline Constants & $0.1082(0.10)$ & $1.5422(1.14)$ & $-8.1337^{\star * *}(-9.37)$ \\
\hline $\mathrm{R}^{2}$ & 0.5115 & 0.5368 & 0.8606 \\
\hline Number of samples & 49 & 49 & 49 \\
\hline Hausman test & 3.64 & & \\
\hline
\end{tabular}

Note: ${ }^{*}{ }^{* *}$, and ${ }^{* * *}$ represent coefficients passing significance tests at the $10 \%, 5 \%$, and $1 \%$ levels, respectively. The corresponding $z$-values are shown in parentheses below the random effects coefficient estimates, while the $t$-values are shown in the fixed effects and mixed regressions. The sample size is reduced by one because there is no data on absorption funding for furniture manufacturing in 2016.

effects, but individual effects may still exist in the form of random effects. This paper determines whether the model uses a fixed-effects model or a randomeffects model based on the results of the Hausman test, and according to the test results this paper selects the random-effects model for the empirical analysis, the empirical results of this paper are analyzed mainly according to column 2 of the table. According to the results, the random effects model should be used.

The following analysis is based on the estimation results of the random effects model. For the variables of technological innovation capability system, the innovation input capability passes the significance test, but its sign is negative, indicating that for every 1 percentage point increase in innovation funding, the international competitiveness decreases by 0.48 percentage points. On the contrary, for every 1 percentage point decrease in investment, the international competitiveness can be increased by 0.48 percentage points; the innovation output capability does not pass the significance test; the import and absorption reinvention capability has a significant positive effect, and for every 1 percentage point increase (decrease) in the proportion of digestion and absorption funding, the international competitiveness of products will increase (decrease) by 0.05 percentage points. By looking at the trend of RCA values of each industry, we can see that more than half of them have a slightly decreasing trend, which means that the international competitiveness level of these industries has slightly decreased. In almost all industries, the investment in innovation is gradually increasing. This suggests that the $\mathrm{R} \& \mathrm{D}$ funding may have been over-invested and there is a dissonance and mismatch between the elements and other aspects, thus 
causing a loss of efficiency. The reason for the insignificant output capacity of innovation may be that it takes time for the products developed by innovation to gain market recognition, so the effect will not be shown too quickly; the significant positive effect of importing and absorbing re-innovation capacity indicates that absorbing and digesting developed foreign technology experience is an important way for China's manufacturing industry to improve the international competitiveness of products.

As for the technological innovation support system, the coefficients of both the proportion of government funds and the proportion of loans from financial institutions are not significant. The reason may be that: one is to consider the path and method of government support for manufacturing development in an overly simplified way, and this paper only selects its help in providing funds for manufacturing industry in this aspect. In addition, the government can also provide a suitable environment for the development of manufacturing industry by means of fiscal measures, industrial policies and innovation platforms, so the simplified treatment has caused the bias of the results. Second, the funds provided by the financial system are calculated in a general way without analyzing the flow mechanism of financial funds in depth. Some studies have shown that the capital market has a significant contribution to the innovation capacity of the manufacturing industry, while the credit market has no significant contribution.

Industry size can significantly affect the international competitiveness of manufacturing products, with each 1 percentage point increase in the industry's product sales revenue ratio increasing its international competitiveness by 0.8316 percentage points. This indicates that the sample industries are still in the rising stage of scale economy. The role of market openness is not significant, probably because most of the sample manufacturing industries are facing a relatively fierce international competitive environment, and market openness alone is not enough for them to develop more effectively.

\subsection{Robustness Testing and Analysis}

In order to improve the accuracy of the research results, the robustness of the model is tested in this paper, the method used is mainly the method of replacing key variables, and the international competitiveness of the manufacturing industry is re-measured and calculated in this paper, so as to re-analyze the empirical results. Before conducting the robustness test, this paper also uses the Hausman test to determine whether to use the fixed-effects model or the random-effects model, and according to the test results, the random-effects model is better than the specified-effects model, so the robustness test in this paper continues to use the random-effects model for analysis. The specific robustness empirical results are shown in Table 4, and it can be seen through the empirical results that the empirical results are consistent with the results of the benchmark regression, and it can be seen that the results of this paper are robust.

Table 4 shows the results of the robustness test. 
Table 4. Robustness results. Author's calculations.

\begin{tabular}{cc}
\hline Variables & $\mathrm{RE}$ \\
\hline $\operatorname{lnIIN}$ & $-0.3279^{\star *}(-2.41)$ \\
$\operatorname{lnIOUT}$ & $0.0258(0.79)$ \\
$\operatorname{lnINAB}$ & $0.0474^{\star *}(2.12)$ \\
$\ln \mathrm{GOV}$ & $-0.0063(-0.59)$ \\
$\operatorname{lnFIN}$ & $0.3564(0.42)$ \\
$\operatorname{lnSCA}$ & $0.7981^{\star * *}(4.12)$ \\
$\operatorname{lnOPE}$ & $0.1562(0.61)$ \\
Constants & $0.1567(0.13)$ \\
$\mathrm{R}^{2}$ & 0.6279 \\
Number of samples & 49 \\
Hausman test & 3.82 \\
\hline
\end{tabular}

Note: ${ }^{*}{ }^{* *}$, and ${ }^{* * *}$ represent coefficients passing significance tests at the $10 \%, 5 \%$, and $1 \%$ levels, respectively. The corresponding $z$-values are shown in parentheses below the random effects coefficient estimates, while the $t$-values are shown in the fixed effects and mixed regressions. The sample size is reduced by one because there is no data on absorption funding for furniture manufacturing in 2016.

\section{Policy Recommendations}

According to the empirical results of this paper, the following policy recommendations are proposed.

First, we should further strengthen the construction of the manufacturing technology innovation capacity system. Since the investment of innovation funds may have reached the stage of diminishing marginal benefits, blindly increasing the intensity of investment is not a reasonable choice. Thus, it is necessary to optimize the investment structure of technological innovation and coordinate the ratio between R \& D personnel and funds; in addition, it is necessary to strengthen the ability of the manufacturing industry to introduce and absorb and digest re-innovation, maintain an open market environment, build an information service platform for manufacturing subjects to understand and learn foreign advanced technology, and encourage the domestic manufacturing industry to actively introduce foreign developed technology and carry out absorption and digestion re-innovation.

Second, we should improve the construction of the manufacturing technology innovation support system. On the one hand, the government needs to evaluate whether the funds invested in the manufacturing industry are in place, and continuously improve and optimize the flow and structure of policy funds; on the other hand, it also needs to continuously build a market environment conducive to the manufacturing industry's technological innovation activities, including the financial market environment consisting of the credit market and capital market.

Third, we should pay attention to the economies of scale of the manufacturing 
industry, and consider expanding the scale of the industry horizontally and vertically to reduce the production cost of products and improve efficiency. At the same time, we should continue to maintain an open market environment to encourage the manufacturing industry to participate in international competition while assisting it in finding ways to enhance its international competitiveness more effectively.

\section{Funding}

This paper is sponsored by China National Fund for National Social Science Research Project: On the Core Theory of Global Layout for China's Strategic Emerging Industry, 17BJL015.

\section{Conflicts of Interest}

The authors declare no conflicts of interest regarding the publication of this paper.

\section{References}

Bai, J. (2011). Is Government R \& D Funding in China Effective? Empirical Evidence from large and Medium-Sized Industrial Enterprises. Economics (Quarterly), 10, 1375-1400.

Brecht, H. J. E. (1992). Australia's Industrial R \& D and Foreign Trade. Applied Economics, 24, 545-556. https://doi.org/10.1080/00036849200000068

Demirel, P., \& Mazzucato, M. (2008). Does Market Selection Reward Innovators? R \& D, Patents and Growth in the US Pharmaceutical Industry. Open University, IKD.

Greenhalgh, C., Mavrotas, G., \& Wilson, R. (1996). Intellectual Property, Technological Advantage and Trade Performance of UK Manufacturing Industries. Applied Economics, 28, 509-519. https://doi.org/10.1080/00036849600000029

Hu, J., \& Liu, S. J. (2015). Research on the Impact of Financial Development on Manufacturing Technology Innovation: A Sample of Nine Sub-Industries with High Technology Intensity in Manufacturing Industry. Industrial and Economic Review, 6, 28-35.

Huang, Q. (2012). China's Industrial Power and Industrial Power Strategy. China's Industrial Economy, 39, 5-16.

Huang, Q., \& He, J. (2015). The Core Competence, Functional Positioning and Development Strategy of China's Manufacturing Industry-A Review of Made in China 2025. China Industrial Economy, 39, 5-17.

Jin, B. (1996). Research on International Competitiveness of Industry. Economic Research, $68,39-44+59$.

Kim, L., \& Nelson, R. R. (Eds.) (2000). Technology, Learning, and Innovation: Experiences of Newly Industrializing Economies. Cambridge University Press.

Lai, M. Y., Wang, J. H., \& Wu, X. J. (1999). An Empirical Study on the Role of Technological Innovation on the International Competitiveness of Chinese Industrial Manufactures. Statistical Research, 39, 15-20.

Li, M., Xiao, H., \& Fu, J. (2014). Fiscal Policy, Corporate R \& D Investment and Technological Innovation Capacity: An Empirical Study Based on Listed Companies in Strategic Emerging Industries. Management Review, 26, 135-144.

Li, Q., Liu, M., \& Jiao, Y. (2019). Technological Innovation, Export Domestic Value Added and Global Competitiveness-Evidence from China's Manufacturing Sector. Macroeco- 
nomic Research, 44, 110-124.

Wu, X., \& Shi, F. (2010). A Study on the Factors Influencing the Independent Innovation Capacity of Pan-Pearl River Delta Region: An Empirical Analysis Based on Panel Data of Nine Provinces. Science and Technology Management Research, 30, 10-12.

Yu, M. Y. (2014). An Empirical Analysis of Technological Innovation and International Competitiveness of China's Manufacturing Industry. Economic and Management Research, $43,13-22$. 